\title{
Tinjauan Alur Prosedur Pelayanan Pasien Rawat Jalan Peserta BPJS di RSU Imelda Pekerja Indonesia Medan
}

\author{
Yeyi Gusla Nengsih
}

Dosen D-4 Manajemen Informasi Kesehatan, Universitas Imelda Medan

\section{Article Info}

Article history:

Received Jan 04, 2021

Revised Feb 18, 2021

Accepted Feb 20, 2021

\section{Keywords:}

Procedure Flow

Outpatient

BPJS

\begin{abstract}
ABSTRAK
Outpatient care is a service intended for patients to seek treatment or other needs without having to stay in the hospital inpatient room. The outpatient registration site starts from the patient registration until the patient receives service. Based on the survey, it was found that if BPJS patients did not complete the requirements such as photocopies of ID cards and family cards, referral letters, photocopies of SKP and photocopies of BPJS cards in a day, these patients would not immediately receive further services. Imelda Indonesia Hospital Medan workers do not have a special registration procedure so that it is still difficult to trace medical record documents in the filling room and also distribution of medical record documents to polyclinics is still very long. This causes BPJS patient services not immediately fulfilled. The research objective was to determine the flow of outpatient procedures for BPJS participants. The research was conducted on Monday to Thursday 08.00 - 11.00 WIB and every Friday to Saturday 09.00 - 11.00 WIB for 1 week. This type of research is descriptive with the population in this study, namely participants of outpatient health BPJS and the object of research at the Imelda Indonesia Workers Hospital, Medan. The instruments used were interviews and direct field observations. Based on the results of the study, it shows that the flow and procedures of BPJS participants are in accordance with standard operating procedures (SOP).
\end{abstract}

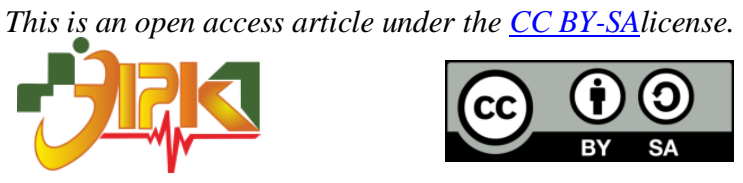

\section{Corresponding Author:}

Yeyi Gusla Nengsih,

Dosen Perekam Medis dan Informasi Kesehatan,

Universitas Imelda Medan,

Jl. Bilal No. 52 Kelurahan Pulo Brayan Darat I Kecamatan Medan Timur, Medan - Sumatera Utara.

Email: yeyigusla22@mail.com

\section{PENDAHULUAN}

Menurut Undang-undang Republik Indonesia Nomor 44 Tahun 2009 Rumah Sakit adalah institusi pelayanan kesehatan perorangan secara paripurna yang menyediakan rawat jalan, rawat inap dan gawat darurat. Sedangkan fungsi dari Rumah Sakit itu sendiri adalah penyelenggaraan pengobatan dan pemulihan untuk pasien sesuai standart operasional prosedur rumah sakit sehingga memerlukan manajemen yang baik dalam pengelolaannya agar mendapatkan citra yang baik kepada masyarakat terhadap rumah sakit. 
Menurut (Shofiana dkk, 2019) dalam artikel yang berjudul "Analisis Proses Pelayanan Pendaftaran Pasien di Puskesmas Jatisrono I Kabupaten Wonogiri” mengemukakan tentang rawat jalan adalah penyelenggaran pelayanan pasien untuk berobat atau keperluan lain tanpa menginap di rumah sakit dan itu merupakan salah satu tanggung jawab rumah sakit untuk mengatur pendaftaran dan penerimaan pasien yang akan dirawat jalan.

Alur prosedur pelayanan di setiap rumah sakit berbeda-beda tergantung dari prosedur dan kebijakan masing-masing rumah sakit khususnya pasien BPJS. Pasien BPJS akan dilayani oleh pihak rumah sakit apabila telah memenuhi segala persyaratan yang ditetapkan rumah sakit itu sendiri yang dikemukakan oleh (Arief , 2009) dengan buku yang berjudul "Metodologi Penelitian Untuk Ilmu Kesehatan".

Bagian TPPRJ melayani pasien dimulai dari pendaftaran hingga pasien mendapatkan pelayanan. Berdasarkan survey terdahulu diketahui bahwa jika pasien BPJS tidak melengkapi persyaratan seperti foto copy KTP dan KK, surat rujukan, foto copy SKP dan foto copy kartu BPJS dalam sehari maka pasien tersebut tidak segera mendapatkan pelayanan lebih lanjut. Hal ini menyebabkan pasien BPJS mengalami kesulitan dalam pendaftaran rawat jalan yang berakibat tertundanya pelayanan atau tidak segera terpenuhi (Arief, 2009).

Di Indonesia pada tanggal 1 Januari 2014 telah didirikan suatu Badan Penyelenggara Jaminan Sosial Kesehatan yang selaras dengan tujuan Organisasi Kesehatan Dunia dalam mengembangkan jaminan kesehatan untuk semua penduduk. BPJS Kesehatan ini merupakan badan hukum yang dibentuk untuk menyelenggarakan program kesehatan (Peraturan BPJS Kesehatan Nomor 1).

BPJS Kesehatan harus memahami kebutuhan pelayanan kesehatan masyarakat yang dilayaninya dalam menentukan cara yang paling efektif menyelenggarakan pelayanan kesehatan bermutu. Zeithaml et al (dalam Rangkuti, 2006) menyatakan bahwa pelayanan yang bermutu berbentuk dari lima dimensi Service Quality (Serqual) yaitu, Kehandalan, daya tangkap, jaminan empati dan bukti fisik (Rangkuti, 2006).

BPJS adalah bentuk bantuan sosial untuk pelayanan kesehatan bagi yang tidak mampu serta peserta lainnya dengan iuran peserta dibayar oleh pemerintah yang diselenggarakan secara nasional dalam rangka mewujudkan pelayanan kesehatan yang menyeluruh bagi masyarakat miskin. Upaya melaksanakan program BPJS harus mengikuti prinsip-prinsip penyelenggaraan yang telah diatur dalam UU SJSN No 40 Tahun 2004. Oleh karena itu, diharapkan kontribusi dan peranan pihak terkait, Puskesmas serta jajarannya, balai-balai kesehatan dan organisasi kemasyarakatan termasuk lembaga-lembaga swadaya masyarakat, pemerintah pusat dan daerah untuk membantu kelancaran program BPJS ini (Rangkuti, 2006).

Tempat Pendaftaran Pasien Rawat Jalan (TPPRJ)

A. Deskripsi Alur dan Prosedur Pelayanan

Menyiapkan formulir dan catatan serta nomor rekam medis yang diperlukan untuk pelayanan. Formulir dan catatan yang diperlukan yaitu :

1. Kartu Indeks Utama Pasien

2. Kartu Identitas Berobat

3. Formulir berkas rekam medis yang telah diberi nomor (formulir RM 1 - RM7)

a) RM 1 : Ringkasan Riwayat Poliklinik

b) RM 2 : Catatan Poliklinik

c) RM 3 : Lembar Konsultasi

d) RM 4 : Lembar Persetujuan Tindakan Medis

e) RM 5 : Hasil Lab

f) RM 6 : Salinan Resep 
g) RM 7 : Biling Pembayaran

B. Prosedur Pelayanan Pasien Baru BPJS

1. Pasien datang

2. Petugas pendaftaran menanyakan tujuan poliklinik yang dibutuhkan pasien

3. Petugas pendaftaran meminta identitas pasien (Kartu BPJS, foto copy KTP, foto copy KK, foto copy pengantar dari puskesmas)

4. Mencatat setiap penggunaan nomor rekam kedalam buku catatan

5. Mencatat identitas pasien berdasarkan kartu BPJS ke dalam formulir rekam medis

6. Mencatat identitas pasien pada buku registrasi pendaftaran serta penggunaan formulir

7. Syarat Kelengkapan BPJS ditempelkan pada dokumen rekam medis pasien

8. Menyerahkan KIB kepada pasien

9. Mengarahkan pasien untuk menunggu sesuai poliklinik yang dibutuhkan

10. Mencatat identitas pada buku ekspedisi TPPRJ

11. Kemudian dokumen rekam medis diberikan dan ditandatangani oleh petugas URJ

12. Membawa kembali buku ekspedisi ke TPPRJ

13. Menyimpan KIUP pada ruang filing berdasarkan sistem penjajaran alphabetic

14. Menerima laporan SHRJ dari URJ

C. Prosedur Pelayanan Pasien Lama BPJS

1. Pasien datang

2. Petugas pendaftaran meminta identitas pasien (Kartu BPJS, foto copy KTP, foto copy KK, foto copy pengantar dari puskesmas)

3. Meminta KIB pasien

4. Nomor rekam medis dicatat berdasarkan KIUP pada tracer

5. Melengkapi dokumen rekam medis kemudian menempelkan semua kelengkapan BPJS pada dokumen pasien

6. KIB diserahkan kepada pasien

7. Mengisi buku ekspedisi TPPRJ

8. Mendistribusikan dokumen rekam medis bersamaan dengan pasien ke poliklinik menggunakan buku ekspedisi TPPRJ

9. Dokumen pasien diserahkan ke URJ dan kemudian ditanda tangani oleh petugas URJ

10. Membawa kembali buku ekspedisi ke TPPRJ

11. Menerima laporan SHRJ dari URJ

\section{METODE PENELITIAN}

A. Jenis Penelitian

Dalam penelitian ini metode yang digunakan adalah metode deskriptif dan obyek penelitiannya adalah alur prosedur pelayanan pasien rawat jalan peserta BPJS di RSU Imelda Pekerja Indonesia Medan.

\section{B. Instrumen Penelitian}

1. Pedoman Wawancara

Pedoman wawancara adalah sekumpulan daftar pertanyaan yang digunakan peneliti untuk bertanya secara langsung kepada narasumber untuk memperoleh data atau informasi mengenai alur prosedur pelayanan pasien rawat jalan.

2. Pedoman Observasi

Pedoman observasi yaitu sekumpulan daftar jenis kegiatan yang akan diamati nantinya untuk mendapatkan data berupa :

a. Pelaksanaan alur prosedur pelayanan 
b. Jenis formulir dan buku catatan yang digunakan dalam pendaftaran

c. Persyaratan pendaftaran

\section{HASIL DAN PEMBAHASAN}

\subsection{Hasil}

Tempat pendaftaran pasien merupakan tempat awal pelayanan rumah sakit yang dibuka setiap hari senin s/d kamis dari jam 08.00 - 11.00 WIB dan setiap hari jumat s/d sabtu dari jam 09.00 - 11.00 WIB. Tempat pendaftaran terdiri-dari 2 loket yaitu loket pertama untuk pendaftaran pasien BPJS dan loket kedua untuk pendaftaran pasien umum. Adapun jumlah petugas pendaftaran terdiri-dari 3 petugas yaitu petugas satu bertugas dalam entry identitas pasien baru dan pasien lama ke sistem database komputer, petugas kedua bertugas sebagai pengelompokkan dokumen rekam medis sesuai poliklinik yang dituju, petugas ketiga bertugas sebagai penyimpanan dokumen rekam medis. Penelitian ini berdasarkan data-data yang mencakup tentang alur prosedur pelayanan pasien rawat jalan sebagai berikut :

1. Alur Prosedur Pendaftaran Pasien Baru Peserta BPJS

a) Pasien datang

b) Petugas pendaftaran meminta identitas pasien untuk melengkapi data seperti :

(1) Kartu BPJS asli

(2) Foto copy KTP

(3) Foto copy KK

(4) Surat rujukan dari puskesmas

(5) Foto copy kartu BPJS

(6) Foto copy akta kelahiran

c) Apabila persyaratan sudah lengkap maka petugas PPATRS menerbitkan Surat Keabsahan Peserta yang dibubuhi stempel dan tanda tangan asli

d) Petugas PPATRS menyerahkan persyaratan peserta BPJS serta formulir bukti pembayaran dan Surat Keabsahan Peserta kepada petugas pendaftaran untuk di entry ke sistem komputer

e) Petugas pendaftaran mengentry data meliputi :

(1) Nama pasien

(2) Nomor rekam medis

(3) Hari/tanggal/jam

(4) Umur pasien

(5) Jenis kelamin

(6) Pekerjaan

(7) Agama

(8) Alamat lengkap

(9) Kliniki yang dituju

(10) Nama keluarga (nama ayah dan nama ibu) atau (nama istri dan nama suami)

f) Petugas pendaftaran mencetak lembar ringkasan riwayat poliklinik kemudian mencatat identitas pasien pada Kartu Identitas Berobat

g) Setelah selesai maka petugas melakukan kegiatan :

(1) Menjumlahkan kunjungan pasien baru BPJS pada hari tersebut

(2) Mencocokkan jumlah pasien di tempat pendaftaran dan dikasir rawat jalan

(3) Berkas dikembalikan ke ruang filing

2. Alur Prosedur Pendaftaran Pasien Lama Peserta BPJS

a) Pasien datang

b) Petugas pendaftaran meminta identitas pasien untuk melengkapi data seperti : 
(1) Kartu BPJS asli

(2) Foto copy KTP

(3) Foto copy KK

(4) Surat rujukan dari puskesmas

(5) Foto copy kartu BPJS

(6) Foto copy akta kelahiran

c) Apabila persyaratan sudah lengkap maka petugas PPATRS menerbitkan Surat Keabsahan Peserta yang dibubuhi stempel dan tanda tangan asli

d) Petugas PPATRS menyerahkan persyaratan peserta BPJS serta formulir bukti pembayaran dan Surat Keabsahan Peserta kepada petugas pendaftaran yang bertugas di ruang filing

e) Petugas melakukan pencarian dokumen sesuai nomor rekam medis

f) Petugas pendaftaran mengentry data pasien kedalam sistem komputer

g) Setelah selesai maka petugas melakukan kegiatan :

(1) Menjumlahkan kunjungan pasien baru BPJS pada hari tersebut

(2) Mencocokkan jumlah pasien di tempat pendaftaran dan dikasir rawat jalan

(3) Berkas dikembalikan ke ruang filing

3. Jenis Formulir dan Buku Catatan

a) Kartu Identitas Berobat yang berisi data lengkap pasien yang diisi langsung oleh petugas pendaftaran kemudian diserahkan kepada pasien

b) Lembar ringkasan riwayat poliklinik yang berisi nama, alamat, umur, jenis kelamin, nomor rekam medis, poliklinik yang akan dituju dan di diagnosis.

c) Formulir bukti pembayaran yang berisi nama pasien, alamat, tanggal lahir, berat badan, tinggi badan, nomor rekam medis, kode ICD-10, diagnosis pemeriksaan, tindakan, kode ICD-9-CM, tanggal verifikasi, nama verifikator, tanda tangan verifikator dll.

d) Surat Keabsahan Peserta yang berisi nomor kartu BPJS, nomor Surat Keabsahan Peserta, identitas kunjungan serta tanda tangan petugas PPATRS.

\subsection{Pembahasan}

\section{Alur Prosedur Pendaftaran Pasien Rawat Jalan}

Alur prosedurnya sudah sesuai dalam pelaksanaannya yaitu apabila berkas pasien tidak ditemukan maka untuk menelusuri berkas itu kembali sangatlah sulit karena digunakan buku ekspedisi. Buku ekspedisi itu digunakan untuk membawa berkas ke poliklinik yang dituju dan mengembalikan kembali ke poliklinik setelah pasien mendapatkan pelayanan.

Pendistribusian dokumen masih terlalu lama sehingga menghambat pelayanan pasien yang dikarenakan petugas poliklinik belum menerima dokumen pasien dari petugas pendaftaran. Berdasarkan hasil wawancara kepada petugas yaitu kurangnya jumlah petugas pendaftaran mengakibatkan tidak digunakannya buku ekspedisi serta pendistribusian dokumen yang terlalu lama. Apabila penggunaan buku ekspedisi dilaksanakan maka dianggap kurang efektif, karena proses pendaftaran pasien akan terlalu lama.

Menurut (Rangkuti, 2006), Alur Pelayanan Rawat Jalan adalah proses urutan pelayanan pasien di rumah sakit sesuai dengan kebutuhan pasien berdasarkan ketentuan yang berlaku. Dalam dimensi ini, pemberi jasa dituntut untuk menyediakan jasa yang mudah dipahami. Jasa yang diberikan jangan sampai mengalami kegagalan, dengan kata lain jasa tersebut selalu baik. Menurut asumsi peneliti bahwa ada kaitan antara teori dengan pendapat pakar, bahwasannya alur pelayanan rawat jalan mayoritas baik, dilihat dari kuesioner yang menilai BPJS Kesehatan memberikan pelayanan rawat jalan yang memuaskan. 
Menurut Peraturan Menteri Pendayagunaan Aparatur Negara dan Reformasi Birokrasi Republik Indonesia Nomor 35 tahun 2012 tentang Pedoman Penyusunan Standar Operasional Prosedur Administrasi Pemerintah, Standar Operasional Prosedur pendaftaran pasien baru rawat jalan jaminan BPJS, termasuk jenis SOP teknis, karena pelaksanannya dalam kesatuan tim dan berisi langkah-langkah rinci dalam pelaksanaan kegiatan. Dalam pelaksanaan masih ada 3 tahapan dalam prosedur tersebut yang belum dilaksanakan secara maksimal. Hal ini kemudian dikonfirmasi kepada informan kunci, didapatkan bahwa untuk prosedur nomor 6 masih ada 3 yang belum sesuai itu dilakukan ketika nomor antrian kosong atau tidak penuh maka pasien dapat langsung mendaftar. Nomor 7 sebaiknya dibuatkan pembuatan SEP dahulu supaya terlihat jenis pasien BPJS PBI dan non PBI atau pengecekan kartu BPJS apakah masih aktif atau belum bayar iuran bisa terlihat kemudian dilakukan pendaftaran ke bagian billing sehingga pendaftaran lebih efektif dan efisien, kemudian untuk permasalahan nomor 8 itu memang tidak selalu dicetak kartu berobat karena selalu hilangpada saat didistribusikan menuju poliklinik yang dituju.

\section{Jenis Formulir dan Buku Catatan}

Buku dan formulir yang digunakan dipendaftaran pasien rawat jalan yaitu surat keputusan Menteri Kesehatan Nomor 686/MENKES/SK/2010 tanggal 2 juni 2010 tentang pedoman Badan Penyelenggaraan Jaminan Kesehatan (BPJS) yang dikeluarkan oleh Kementerian Kesehatan RI. Yang mana menjadi kelengkapan persyaratan pasien rawat jalan yaitu foto copy kartu BPJS, foto copy KTP dan KK dan surat rujukan untuk mendapatkan SKP yang berisikan nomor kartu BPJS, nama, tanggal lahir, jenis kelamin dan alamat asal pasien yang dibubuhi dengan stempel, nama dan tanda tangan petugas PPATRS. Hal ini sesuai dengan teori bahwa kartu BPJS/identitas kepesertaan dibawa keloket PPATRS untuk diverifikasi kelengkapannya dan selanjutnya dikeluarkan Surat Keabsahan Peserta oleh petugas PPATRS.

\section{KESIMPULAN}

Alur prosedur pelayanan pasien sudah sesuai dengan standar operasional prosedur (SOP) rawat jalan. Akan tetapi, apabila data-data pasien lama rawat jalan tidak ditemukan diruang filing serta pendistribusian dokumen juga masih lama maka akan menyebabkan pelayanan poliklinik terhambat dan pasien menunggu terlalu lama.

\section{REFERENCES}

Arief, M. (2009). "Pengantar Metodologi Penelitian Untuk Ilmu Kesehatan". Surakarta: Sebelas Maret University Press. Hal 53-4.

Arikunto, S. (2006). "Prosedur Penelitian Suatu Pendekatan Praktik". Jakarta: Rineka Cipta. Hal 23.

Depdiknas. (2008). “Kamus Besar Bahasa Indonesia”. Jakarta: PT Gramedia.

Depkes, RI. (1991). "Petunjuk Teknik Penyelenggaraan Rekam Medis". Jakarta: Departemen Kesehatan RI. Hal 3.

Kemenkes, RI. (2010). "Pedoman Pelaksanaan Jaminan Kesehatan Masyarakat 2010". Jakarta : Kemenkes RI, Hal 1. 
Nengsih, Y.G (2020). "Sistem Antrian Rekam Medis Pasien di Rumah Sakit Menggunakan Model Multi Channel Dengan Pola Poisson”. Jurnal Ilmiah Perekam dan Informasi Kesehatan Imelda, Vol. 5 No. 2 Hal. 121-131.

Nengsih, Y.G (2020). "Sistem Informasi Penjualan Jilbab Pada Toko Karunia Bukittinggi Dengan Bahasa Pemrograman PHP dan My SQL". Jurnal Pendidikan Teknologi Informasi (JUKANTI), Vol. 3 No. Hal. 1 21-28.

Prasasti, T.I. (2017). "Keamanan dan Kerahasiaan Berkas Rekam Medis Pasien di RSUD Prijonegoro Sragen”. Jkesvo, Vol. 2 No. 1 Hal. 23-30.

Shofiana, B.N dkk (2019). "Analisis Proses Pelayanan Pendaftaran Pasien di Puskesma Jatisrono I Kabupaten Wonogiri”. Jurnal Kesehatan Masyarakat, Vol. 7 No. 1 Hal. 102-112.

\section{BIOGRAPHIES OF AUTHORS}

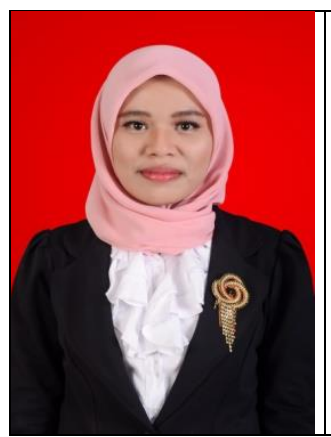

Yeyi Gusla Nengsih, Gelar Sarjana diperoleh dari Universitas Putra Indonesia YPTK Padang, Jurusan Ilmu Komputer pada Tahun 2017. Magister Ilmu Komputer diperoleh dari Universitas Putra Indonesia YPTK Padang pada Tahun 2018. Saat ini aktif sebagai pengajar di Program Studi D-III Perekam dan Informasi Kesehatan Universitas Imelda Medan. 